\title{
Gender and Human Rights: An Evaluation of Women's Right in Islam
} Mashood Omotosho Ph.D ${ }^{1 *}$, Serifat Babarinde Asiyanbi ${ }^{2}$

${ }^{1}$ Department of International Relations Obafemi Awolowo University Ile-Ife, Nigeria

${ }^{2}$ Department of Political Science and International Relations Crescent University Abeokuta, Nigeria

DOI: $\underline{10.36348 / \text { sjhss.2020.v05i06.008 }}$ | Received: 02.03.2018 |Accepted: 18.03 .2018 | Published: 21.06 .2020

*Corresponding author: Mashood Omotosho Ph.D

\section{Abstract}

In the international system today, the issue of human rights networks have become very sophisticated, dense and multifaceted. Scholars and many authors in the realms of human rights have therefore taken special care to highlight divergent perspectives and encourage debate across global cleavages of all kinds. The issue of women's rights in Islam has generated series of controversy, great misunderstanding, and distortion partly due to lack of understanding and the misbehaviour of some Muslims which has been taken to represent the teaching of Islam. This paper therefore aims to provide a better understanding and awareness of women's right in Islam and portray that the religion of Islam grants enormous rights to women just like other key human rights organisations. The paper also unravels the misnomer and incongruity on the perspective that Islamic law subjugates or undermines women's rights.

Keywords: Sharia, Women's Rights, Gender, Islam, Muslims, Human Rights.

Copyright @ 2020: This is an open-access article distributed under the terms of the Creative Commons Attribution license which permits unrestricted use, distribution, and reproduction in any medium for non-commercial use (NonCommercial, or CC-BY-NC) provided the original author and source are credited.

\section{INTRODUCTION}

The histories of Women's rights in Islam in regions like Europe, South and Eastern Asia as well as Africa are embedded in claims to power and contestations over the meanings of symbols and practices [1]. The issue of women's right in Islam is a topic of great misunderstanding and distortion partly due to lack of understanding and misbehavior of some Muslims which has been taken to represent the teachings of Islam. The rights of women, inter alia, have been one of the most controversial and debatable issues in academic circles and politics, especially in the contemporary world order. The dilemmas and better understanding of women's right in Islam are not problems in Islam, but it is one of the most extremely misunderstood and incorrectly portrayed things in the western society. It should be emphasized that one of the major controversial issues in the realms of human rights, especially for those who do not know the truth in the Holy Quran and Hadiths of the Holy Prophet Mohammed (Peace be unto him- PBUH) is about the women's rights and their roles in the political system or in leadership. As Erturk has rightly observed, the status of women has been subjected to different articulations vis-à-vis Islam and secularism, along with modern and traditional tendencies [2].
The religion of Islam has had a deep historical presence and has been a central driving force in the reconceptualization of increasing pluralist states as well as the consequences of various failures. Yet, the issue of women's rights in Islam remains under-examined by mainstream scholars in the social sciences. These developments have not been without consequence. For as increasing numbers of new local Islamic institutions and networks of trade and sociality continue to take shape, global controversies related to disjuncture in Islamic and neo-liberal contexts are becoming increasingly acute. Nevertheless, opposition to Islam is longstanding and has been interconnected with the conquests over land, power, economy and allegiance to the state $[3,4]$.

On one hand, there are Western academics, intellectuals and scholars who project the view, especially in the mass media, that Islamic law is exploitative towards women and gives them an inferior or secondary status when compared to men. They claim that Islamic law is discriminatory, inhumane and degrading and that it restricts the freedom of women which is automatically guaranteed in Western societies functioning under liberal constitutions [5]. Within the contemporary global politics, there are Islamic events relating to politics and social change in the international system, and these have been at the forefront of international community in combination with secular 
consciousness like never before. It should also be reiterated that the development of modern secular state has led to the reinforcement of particular norms such as women's rights, individual rights, democratic governance and Islamic revivalist movements are having a profound effect on many of the presumed norms of secular authority.

Muslim scholars and intellectuals assert that, the rights of women, as laid out in the Quran 1,400 years ago, give men and women equal rights and fair basis for interaction in all aspects of life. It is factual that Islamic law protects the honor and dignity of women, is universally applicable in all human societies and valid for all time to come. It gives both men and women equal status and it is not discriminatory at all. If anything, Islam gives women complete independence and freedom in their economic, social, personal, political and other realms of life. Their counter charge is that Western talk of women's liberation and equality "is actually a disguised form of exploitation of her body, deprivation of her honor and degradation of her soul" [2, 6] Women's right in Islam is organized in different sects having necessary structures for legal recognition in Islam. The right of women in Islam is embedded within national dimension as well as in international dimension. The long discussed subject of women's rights in Islam is accommodated to include those issues of religious policy of women's role in governance, religious freedom and the relation of women's rights. The doctrines of women's rights preached by Islam deserve the respect of the state in as much as it did not contradict human dignity and this is the litmus of goodies in respect to the women's rights in Islam. Since human dignity is maintained through the respect and guarantee of human rights, it follows that the Islamic institution has divine mission to educate, promote and respect human rights for social cohesion [7]. What is practiced by some Muslims, and the way Muslim women are treated in the so called Islamic states is at considerable deviance from what has been prescribed by the Holy Quran and Hadiths of the Holy Prophet Muhammad (PBUH). Such misnomer usually ends up with a distorted picture of the status given to women in Islam. Some Muslims, even Sheiks and prominent Islamic scholars treat women as secondary citizens, but it should be noted that, such deeds are not prescribed in Islamic laws and practices. Any argument or saying that Islamic law subjugates or undermines women in Islam is a misnomer and incongruity altogether.

Women's position around the world has aroused great interest in global politics and human rights issues. What role do Islamic thoughts and principles play in the oppression of women in secular states and where Islam holds sway? This paper therefore hopes to build a greater understanding and awareness of women's rights in Islam and to portray that the religion of Islam grants enormous rights to women just like other key actors in women's rights movements and organizations and other progressive social movements. This paper will also analyze the strategic knowledge, tools and frameworks on the issue of women's rights in Islam. This study falls within the framework of the broader of women's rights in Islam which also aims to contribute to greater strategic thinking, dialogue, advocacy on women's rights and to develop more knowledge and resources on the issue.

\section{Misconception on Women's Rights in Islam}

It should be noted that, the rights given to women under Islamic injunction should be examined from the authentic sources of the religion of Islam and that is, the Quran and the Sunnah of the Holy Prophet Muhammad (PBUH). The Quran more importantly which the Muslims consider to be the uncontestable and final word of Allah, as revealed to Prophet Muhammad (PBUH) in the 7th century AD. The Quran is a complete code for life and it provides guidance on every issue and situation one can possibly encounter in life. The Quran is unalterable because Allah Himself says in the Quran that He will protect it at all time to come. The Hadiths of the Holy Prophet Muhammad (PBUH) consists of the traditions of Prophet Muhammad (PBUH) and these consist of three things the sayings of the Prophet, the actions of the Prophet and those things which the Prophet did not object to when they happened in his presence - that is he gave tacit approval to them [8]. The Hadiths is the second authoritative body of knowledge. Together, the Holy Quran and the Hadiths of the Holy Prophet Muhammad (PBUH) are the two primary sources of Islamic law, or fiqh. These texts offer a philosophy of life guided by principles and rules through which the faithful could participate in their own regulation. In most Islamic interpretations, like many religious traditions, these religious texts are living documents through which people have the power to apply core principles to changing social contexts [1].

It should be emphasized that, the two authoritative sources the Holy Quran and Hadiths granted women dignified and respected positions in all ramifications; from the spiritual, economic, social, marital and political standpoint. Islam is innocent of the oft-made accusations that, it is an obstacle in the way of total equality of women in civil rights, education and employment which affect all their aspects of life, especially in the realms of socio-economic and political dispensation. The Western media has played an important role in perpetuating divergent misconceptions about the rights of women not only in the religion of Islam but within our community. Why then is Islam portrayed as a religion that oppresses women and puts them in a position inferior to men? Part of that is certainly due to the stereotyped image of how Islamic women are portrayed in western media as an extension of Islam-bashing. A prominent example is the movie "Not without My Daughter" in which scores of false 
and fictitious depictions was made of women in an Islamic country [9]. It is also true, however, that in many so called "Islamic" countries; women are not treated according to their God-given rights. Much of the practices and laws in "Islamic" countries have deviated from or are totally unrelated to the origins of Islam and the teaching of the Holy Quran and Hadiths of the Holy Prophet Muhammad (PBUH). Instead many of these practices are based on cultural or traditional customs which have been injected into Islamic tenets and principles. It should be reiterated that there are widespread erroneous misconceptions about the status and rights of women in Islam. This misconception was augmented by some news media that made little effort to correct their understanding before broadcasting their views on this matter. Adding to this misconception are the regrettable practices in the so called "Islamic" countries or societies where myths, traditions and innovations have won over the true Islamic (Quranic) teachings and where women are traditionally subdued and oppressed. As Ragab rightly observed, these scenarios cannot be attributed to the fault of Islamic ideology or religion of Islam but rather the misapplication or sometimes the outright denial of the ideology in these societies [10].

In Saudi Arabia for instance, women are not allowed to drive by law. This rule, in a country which is supposed to derive its law from Islamic legislation, is completely an invention of the Saudi monarchy. These horrific rules as well as a host of others are residues of old pre-Islamic tribal traditions where women were not entitled to the same rights as men. Also, in some "Islamic" countries, many civil laws remain those that were imposed upon them during European colonization. Again in Egypt, much of the civil law that legislates personal and family matters are directly based on old French law. As a result, an Egyptian man can divorce his wife much more easily than the reverse. Consequently, women often have to suffer long and expensive court procedures and have to prove that they were mistreated by their husbands before being granted a divorce. Often times, laws in Middle Eastern countries, which are legislated and enforced by men, only take bits and pieces of Islamic law and combine them with concocted rules based upon some cultural or foreign practices. Many people have held on to such negative view of Islam, especially when women's issues are involved. In the West, Islam is believed to be the symbol of the subordination of women par excellence $[10,11]$.

The social structure in some countries where Islam prevails encourages the woman to make her house her first priority but there is no prohibition whatsoever on women having to work and earn their living. The Muslim woman has been given the privilege to earn money, the right to own property, to enter into legal contracts and to manage all of her assets in any way she pleases. She can hold a job or run her own business and no one has any claim on her earnings including her husband. Historically, Mohammed's first wife was a merchant who hired Mohammed to work for her. In time past, Muslim women go along with their husbands, fathers and brothers to battle fields to take care of the wounded and help at the back lines of the troops. According to Islamic injunctions and the Quran, women have no limitations on their moves, travels or activities. Men who hire agents to mentor women's moves do this out of their own wishes, not because of any religious law in the Quran. However, this has been a common misconception even among some Muslims which has no basis in the Quran or the Hadiths of the Holy Prophet Mohammed (PBUH). On the contrary, God meant both the women and men to be together with no preference whether in public, work or worship places. Hajj (pilgrimage) is a vivid example of how women and men are not segregated as they worship in the same place, then go ahead with their lives and practice commerce after Hajj with no limits [12]. In the Qur'an, in the first verse of the chapter entitled "Women," God says, "O mankind! Be careful of your duty to your Lord who created you from a single soul and from it its mate and from them both have spread abroad a multitude of men and women. Be careful of your duty toward Allah in whom you claim (your rights) of one another, and towards the wombs (that bore you). Lo! Allah has been a Watcher over you." (Q4:1).

Only in the recent time that emphases are been laid on women's rights, the United Nations Convention on the Elimination of All forms of Discrimination against Women was adopted in 1979 by the United Nations General Assembly. It is often described as an international bill of rights for women, through which we can see how the state and local civil society groups are grappling with identifying what should be women's rights and the dilemmas the state faces in securing these rights. In 1995, United Nations Fourth World Conference for Women in Beijing ratified the Convention on the Elimination of all Forms of Discrimination against Women (CEDAW). The United Nations Declaration on the Elimination of Violence Against Women General Assembly resolution 48/104 was passed in December 1993, recognising that effective implementation of the Convention on the Elimination of All Forms of Discrimination against Women would contribute to the elimination of Violence Against Women and that the Declaration on the Elimination of Violence Against Women, set forth in the present resolution, will strengthen and complement that process. It is only recently that states are obligated to review the impact of existing laws on women, change those laws which discriminate against women, and submit periodic reports to the United Nation Division for the Advancement of Women (DAW) on their progress. CEDAW's principle of state obligation requires nation states not only to bring their domestic laws in line with the Convention, but also to ensure the 
practical realization of rights by undertaking extra measures to implement enabling conditions so that women's capacity to access the opportunities provided is enhanced. Article 5 asserts that states must strive to modify "the social and cultural patterns of conduct of men and women" to eliminate prejudice based on stereotyped beliefs of the inferiority of women $[13,14]$. It should be reiterated that for over 1400 years ago, The Holy Quran and the Hadiths of the Holy Prophet Mohammed (PBUH) have underscored all these basic rights. These rights aim at conferring honor and dignity on women and eliminating exploitation, oppression and injustice to women have been an ideal code of human rights in Islam over fourteen centuries ago. Human rights in Islam are firmly rooted in the belief that God, and God alone, is the Law Giver and the Source of all human rights. Due to their Divine origin, no ruler, government, assembly or authority can curtail or violate in any way the human rights conferred by God, nor can they be surrendered. The rights of women are given to us by Allah (SWT), who is All-Compassionate, AllMerciful, All-Just, All-Unbiased, All-Knowing and Most Wise. The rights that are granted to women are taught in perfect example by the Holy Prophet Muhammad (PBUH).

Allah (SWT) says in the Holy Quran:

O You who believe! You are forbidden to inherit women against their will, and you should not treat them with harshness, that you may take away part of the Mahr (bridal-money given by the husband to his wife at time of marriage) you have given them, unless they commit open illegal sexual intercourse. And live with them honorably. If you dislike them, it may be that you dislike a thing and Allah brings through it a great deal of good. (Q 4:19)

The most basic right of a woman in Islam is the knowledge and recognition that she never has to ask or demand or fight for her rights which are guaranteed to her by Allah (SWT) Himself. It is unfortunate that human rights are being trampled upon with impunity in many countries of the world, including some Muslim countries. Such violations are a matter of serious concern and are arousing the conscience of more and more people throughout the world.

\section{Juxtaposing the Universal Declaration of Human's Right and Women's Right in Islam}

The United Nations Universal Declaration on Human Rights (UDHR) recognized and also provided inherent dignity, equal and inalienable rights to all members of the human family as the foundation of freedom, justice and peace in the world. The African Charter on Human and Peoples' Rights (the African Charter) recognizes human rights as rights that are inherent in all of us simply by birth and existence. They are the rights that we have simply because we are born as human beings. It should be noted that human rights have universal application without bias to gender, race or class (or other social category). In principle, women's human rights are automatically inherent in the general principles of human rights. However, as a result of long standing discriminatory practices against women and the non-recognition of women's rights as being embedded in human rights doctrines, it has become clear that it is absolutely necessary to make a clear delineation of women's rights so that they are not constantly ignored and violated under the mistaken belief that women's rights can be effectively recognized and protected in a presumption to the general principles of human rights [29]. The Universal Declaration of Human Rights (UDHR), the African Charter on Human and Peoples Rights (ACHPR), Application and Enforcement - Act Cap 10, the Convention on the Elimination of all Forms of Discrimination Against Women (CEDAW), the International Labor Organization (ILO) and the Convention on the Political Rights of Women of 1953 provides that women shall have all the political rights that are afforded to men, including the right to vote in all elections as well the right to run for, and to hold public offices. The concepts of gender equality in Islam also portray and support Civil, Social, Economic, Political and Cultural rights of women. The Islamic laws and principles further stress the non-superiority of either sex over the other. It elevates the demeaned status of women and grants them rights equal to those of men. The equality of women in Islam is evident by the unprecedented legal rights given to them under a monotheistic religion as defined in the Quran [8].

According to the Holy Quran, men and women have the same spirit, there is no superiority in the spiritual sense between men and women (Q4:1, Q7:189, Q42:11)[28]. Islam removes any notion of superiority; in terms of moral, spiritual duties, acts of worship, the requirements of men and women are the same, except in some cases when women have certain concessions because of their feminine nature, their health or the health of their children (Q49:13). Another version adds, "And also did not favour his sons over daughters." For instance, there was a time when the Holy Prophet Muhammad (PBUH) was seated and a companion was sitting with him. Then the companion's son came, he kissed and put him on his lap. Then his daughter came, but he just sat her by his side. The Prophet told the man, "You did not do justice". This denotes that he should have treated the daughter equally, kissed her and put her on his lap too. Indeed, whenever the Prophet's daughter Fatimah came to him, in front of everyone, he stood up, kissed her and let her sit in his favorite place where he'd been sitting (Women's Rights in Islam, http://www.islamswomen.com/articles/women_in_dawa h). Again, on another occasion, the Holy Prophet Muhammad (PBUH) spoke of mothers. In a very succinct statement, Prophet Muhammad (PBUH) said, "Paradise is at the feet of mothers." Furthermore, a man once came to him and asked, "O, Messenger, who 
among mankind is worthy of my kindness and love?" The Prophet answered, "Your mother." "Who next?" "Your mother." "Who next?" "Your mother." Only after the third time did he said, "And your father." Prophet Muhammad (PBUH) echoed what the Quran said, "I command you to be kind to women." In one of his last commands in his farewell pilgrimage before his death, he kept repeating, "I command you to be kind and considerate to women." In another Hadiths, he said, "It is only the generous in character who is good to women, and only the evil one who insults them." It is related from Talhah ibn Mu'âwiyah as-Salamî who said: I came to the Prophet and said, "O Messenger of Allah, I want to perform Jihad in the way of Allah. He asked, "Is your mother alive?" I replied, "Yes." The Prophet then said: "Cling to her feet, because paradise is there" [15]. Our women deserve special care and protection, the religion of Islam treats women as a treasure that should be guarded and protected from being distressed at or molested or inconvenienced in our society. Islam protects even the inner feelings of women $[16,17]$.

Another contentious issue in relations to the rights of women in Islam is the issue of equality. In the West, "equality" of men and women means similar rights for both the genders. Women should have exactly the same rights as men for them to be equal. A large number of Islamic scholars disagree with this definition of equality. For them, the idea that men and women should compete with each other to have the same rights does not make any sense. "In Islam equality does not mean identicality." Muslims believe that men and women do not have to have the same rights to enjoy a status of equality. This concept is explained in the context of the intrinsic and natural differences in the biological, emotional, psychological and physiological differences that exist in a man and a woman [18]. These natural differences make one gender more suitable for some functions and the other more suitable for different functions. So in Islam, gender defines the role of a man and woman. Gender roles are considered to be complimentary and not conflicting with each other. A role of a man and a woman is that of a partnership and not a contradictory struggle for supremacy over each other. Western women, in trying to achieve the same rights as men, loose the uniqueness which is inherent in their own gender and only end up degrading themselves. Quran says that both genders have superiority over the other in different areas and one should not try to mimic the other [8]. According to the Quran, men and women have the same spirit; there is no superiority in the spiritual sense between men and women (04:1, 07:189,042:11). The Prophet (PBUH) said: "The most perfect believers are the best in conduct. And the best of you are those who are best to their wives." God tells us $\mathrm{He}$ created mates and put love, mercy, and tranquility between them.

The International Covenant on Economic, Social, and Cultural Rights and the International
Covenant on Civil and Political Rights provide that the enumerated rights shall be equally granted without regards to sex, religion, or race (The Convention on the Political Rights of Women, 193 U.N.T.S. 135, entered into force 7 July 1954). The Islamic laws also provide all these fundamental rights to women 14 centuries ago and till date. As for social rights, Islam has always recognized the prominent role that women play in the society. It should be noted that, even in Europe not until the 19th century, women did not have the right to own their own property. When they are married, they either transfer their property to their husbands as they would not be able to dispose it without permission from their husbands. In Islam, a woman has the basic freedom of choice and expression based on recognition of her individual personality. First, she is free to choose her religion. The Qur'an states: "There is no compulsion in religion. Right has been made distinct from error" (Q2:256). If the woman has any earnings during her marital life, by way of investments of her property, she doesn't have to spend one penny of that income on the household, it is entirely hers. The full maintenance and support of a married woman is the entire responsibility of her husband, even though she might be richer than he is. She doesn't have to spend a penny. In Britain, which is probably perhaps the first country to give women some property rights, laws were passed in the 1860's known as "Married Women Property Act." It is noteworthy that, for more than 1,300 years earlier, Islam has clearly established the rights of women to own property, "Whatever men earn, they have a share of that and whatever women earn, they have a share in that." (Q4:32). In Suratul An-Nisa, declares that, O ye who believe! Ye are forbidden to inherit women against their will. Nor should ye treat them with harshness, that ye may take away part of the dower ye have given them,-except where they have been guilty of open lewdness; on the contrary live with them on a footing of kindness and equity. If ye take a dislike to them it may be that ye dislike a thing, and Allah brings about through it a great deal of good. (An-Nisa 4:19)

Islam has established basic rights for women to have property and financial security. If the woman happened to own any property prior to marriage, she retains that property after marriage and it remains under her control. This guardianship and greater financial responsibility is given to men, Islam requires that they provide women with not only monetary support but also physical protection and kind and respectful treatment. The Muslim woman has the privilege to earn money, the right to own property, to enter into legal contracts and to manage all of her assets in any way she pleases. She can run her own business and no one has any claim on her earnings, including her husband. The Quran states: "And in no wise covet those things in which Allah hath bestowed His gifts more freely on some of you than on others; to men is allotted what they earn, and to women, what they earn; but ask Allah of His bounty, for Allah hath full knowledge of all things" 
(Q4:32). In Islam, the woman keeps her own last name, and her own identity. A Muslim woman is not permitted to change her family name to her husband's name upon marriage. She is always known by her father's name, as a mark of her own identity. The Holy Quran thus states: "And they (women) have rights similar to those (of men) over them, and men are a degree above them" (Q 2:228). Such degree is Quiwama (maintenance and protection). This refers to that natural difference between the sexes which entitles the weaker sex to earn protection. It implies no superiority or advantage before the law. Yet, man's role of leadership in relation to his family does not mean the husband's dictatorship over his wife. Islam emphasizes the importance of taking counsel and mutual agreement in family decisions [19, 20].

They are given the freedom to pursue any profession including political positions. Both in the past and present day, women in Islamic societies have reached political heights unparalleled in the most "advanced" western nations. Even in the earliest day of Islam, Aysha, the wife of the prophet, led an army of 30,000 soldiers. Muslim women lead two Islamic countries: Benazir Bhutto served as the Prime Minister of Pakistan and was a strong and remarkable leader. Turkey was also headed by a Muslim woman, Tansu Ciller, who was elected the Prime Minister in 1993 [8]. In the most authentic collection of Hadith, Hadith Bukhari, a section is devoted to the participation of women, not only in public affairs, but also in the battlefield, and it is needful to state that they function not only as logistical support. Women carried arms, and when there was great danger to the Muslims, they volunteered to participate even in the battlefield. Political rights have been given to Muslim women by God over 1,400 years ago, and that is the right to vote [21]. On any public matter, a woman may voice her opinion and participate in politics. An instance narrated in the Quran (60:12), is that the Holy Prophet Muhammad (PUBH) was instructed that when believing women come to him and swear their allegiance to Islam, he must accept their oath. This establishes the right of women to select their leader and publicly declare such. Finally, Islam does not forbid a woman from holding important positions in government. Abdur-Rahman Ibn Auf consulted many women before he recommended Uthman Ibn Affan to be the Caliph [21].

Islam gives room for women participation in political affairs, the verses quoted earlier, which speaks about men and women being supporters and helpers of each other was taken by some jurists to mean that it also involves public life. How could they ordain the good and forbid the evil without women being active in the affairs of their society? According to the Quran 60:12, we read about Muslim women making "bayy'ah" to the Prophet. Bayy'ah an Islamic term, is somewhat analogous, to a degree, to what we could call an election, or oath of allegiance. And that was given in his capacity not only as a Prophet, but as the Head of State in Medina. The role of woman in the history of the world is demonstrated in the story of Belquees, the Queen of Sheba. (See Q27:22-44). God gave us her history in the Quran, to set precedence that a woman in the capacity of a political leader is not offensive to God. She represents a democratic ruler who consults her people before making important decisions (Q27:29). Sheba's history provides us lessons that God has placed no restrictions on a woman in a leadership role. Contrary to what the traditional Muslim scholars and man-made Hadiths books advocate, a woman as a political leader or Head of State is not against God's system or against the Quran. It might be against the chauvinistic views of some men who misconceive the basis and roles of women as stated in the Holy Quran and Hadiths.

Muslims are charged with the responsibility of promoting human rights through their teachings. The religious institutions need governments who respect human rights. Today people think that women are liberated in the West and that the women's liberation movement began in the 20th century. Actually, the women's liberation movement was not begun by women but was revealed by God to a man in the seventh century by the name of Muhammad (PUBH), who is known as the last Prophet of Islam. The Quran and the Traditions of the Holy Prophet Muhammad (Hadith or Sunnah) are the sources from which every Muslim woman derives her rights and duties [22]. Islam, since fourteen centuries ago, made women equally accountable to God in glorifying and worshipping Him - setting no limits on her moral progress. Also, Islam established a woman's equality in her humanity with men. The goal of Islamic teachings is to promote human dignity, which is attained only through respect of human rights, and explicitly promoting human rights. For instance, during the reign of Umar, women participated in law making. Umar made a proposal of a certain regulation concerning marriage. A woman in the mosque stood up and said, "Umar, you cannot do that." 'Umar did not tell her, "Shut up, you are a woman, you have nothing to do with politics." He asked, "Why?" She made her argument on the basis of Quran. In front of everybody, he stood up and said, "The woman is right and Umar is wrong," and he withdrew his proposal [14]. That was the spirit in the early days of Islam. In the most authentic collection of Hadiths, Hadiths of Bukhari, a section is devoted to the participation of women, not only in public affairs, but in the battlefield. Women carried arms, and when there was great danger to the Muslims, they volunteered to participate even in the battlefield.

The basic goals and aims of the Islamic doctrine on fundamental human rights centers on ensuring equality of rights and duties of men and women, guaranteeing the progress of human beings and 
support the effective participation of all in the political, economic, social and cultural life. The fundamental human rights and liberties of women are guaranteed under Islamic doctrine. They are a common heritage of all Muslim men and women, whose duty is to transmit it from one generation to another in order to preserve it and keep it inviolable. All persons are equal before the law; the Islamic laws guarantee the rights and freedoms of every person regardless of ethnicity, race, sex, language, faith, political beliefs, education, social or property status. All Muslims have the same rights and freedom and are equal before the law regardless of differences in gender, race, nationality, language, religious, social origin, beliefs, and personal or social position. Though, it should be noted that, privileges were established by Islamic injunctions but they are in accordance with the principles of social justice as stated in the Holy Quran and Hadiths of the Holy Prophet Muhammad (PBUH). Both men and women are accountable for their deeds before the law. Like men, women are entitled to seek for justice. Islam asserts that both genders are honored and dignified: And they are equal in the sight of Allah, as they have the same religious and moral duties and responsibilities. In addition, both would face the same consequences of their actions [23].

Democratization of the state means promotion of Human Rights. Religion plays a big role in establishing democratic principles for political organization in societies. Indirectly the religious institutions are promoting human rights as their teachings touch most elements of human rights. All lawful religious doctrines help our societies to promote and protect human rights [3, 24]. Although the fundamental values of every major religious tradition defend the dignity and rights of human beings, some religiously derived beliefs and practices do promote or tolerate violence and discrimination against women. Some of these practices, such as female genital mutilation and early age marriage are sometimes carried out in the name of religion, even though they are typically based in old cultural traditions. In such cases, propaganda by key religious leaders in pointing out practices that do not comply with religious principles might be fundamental in addressing and ending those demeaning traditions $[17,5]$.

The duties husbands and wives are their mutual responsibilities. They may not be identical duties, but the totality of rights and responsibilities are balanced. All these are well established in the Holy Quran, "Women have the same rights (in relation to their husbands) as are expected in all decency from them, while men stand a step above them" (Q2:228). This only specifies the degree of responsibility, not privilege, in man's role as provider, protector, maintainer and leader of the family. When there are family disputes, first the Quran appeals to reason and the consideration of the positive aspects of one's spouse,
"Dwell with your wives in kindness for even if you hate them, you might be hating someone in whom God has placed so much good" (Q4:19). The Prophet Muhammad (PBUH) was full of praise for virtuous and chaste women. He said: "The world and all things in the world are precious but the most precious thing in the world is a virtuous woman". He once told Khalifah Umar: "Shall I not inform you about the best treasure a man can hoard? It is a virtuous wife who pleases him whenever he looks towards her, and who guards herself when he is absent from her." Amongst the clearest examples of Islam honoring women is the great status of motherhood in Islam. Islam commands kindness, respect and obedience to parents and specifically emphases and gives preference to women. Islam raises parents to a status greater than that found in any other religion or ideology $[25,20]$. Narrated Mu'awiyah alQushayri: I went to the Apostle of Allah, Prophet Muhammad (PBUH) and asked him: "What do you say (command) about our wives?" He replied: "Give them food what you have for yourself, and clothe them by which you clothe yourself, and do not beat them, and do not revile them." (Hadith - Sunan Abu Dawud: Book 11, Number 2139) "The best of you is one who is best towards his family and I am best towards the family". "None but a noble man treats women in an honorable manner. And none but an ignoble treats women disgracefully" (Hadith -At-Tirmithy).

In Islam a woman is a completely independent personality. She can make any contract or bequest in her own name. She is entitled to inherit by her position as a mother, as a wife, as a sister and as a daughter. She has perfect liberty to choose her husband. The pagan society of pre-Islamic Arabia had an irrational prejudice against their female children whom they used to bury alive. The Messenger of Allah (PBUH) was totally opposed to this practice. He showed them that supporting their female children would act as a screen for them against the fire of Hell. The Sharia law regards women as the spiritual and intellectual equals of men. The main distinction it makes between them is in the physical aspect based on the equitable principle of fair division of labor. It allots the more strenuous work to the man and makes him responsible for the maintenance of the family. It allots the work of managing the home and the upbringing and training of children to the woman, work which has the greatest importance in the task of building a healthy and prosperous society[12].

\section{CONCLUSION}

It is pertinent to state that not every nation from the very beginning includes gender equity rights in its constitution. Howbeit, these rights may later be included as part of their legal system through statutes, codes, or common law. In such situations, however, it will likely take longer period to include these rights in the legal system in a piecemeal fashion. For example, the United States constitution applies broadly to grant certain inalienable rights to all human beings within its 
borders, however, laws in the United States did not originally provide equal treatment to both sexes. It was not until almost 150 years after the United States constitution was adopted that women in the United States were guaranteed the right to vote. Women were also discriminated against in employment, wages and other realms. Even now, in developed countries, women are not granted respect, dignity and honor, let alone equal pay for equal work.

In Islam, women's rights and the democratic principles are the corner stone of the religion, which is very explicit and well grounded in the Holy Quran and the Hadiths of the Holy Prophet (PBUH). The religion of Islam protects the dignity of women and in conformity with the Universal Declaration for Human Rights [26] that promote and protect Human Rights. Human rights had been embodied in the Quran six centuries before the Magna Carta and nearly 1,400 years earlier than that of the United Nations Declaration on Human Rights. Islamic laws state in clear terms the rights for everyone, Muslim and non-Muslim, even for unbelievers - thus its basic concept of justice is universal [27]. Islamic laws no doubt accommodate women's rights in every sphere of life and women under Islamic laws and injunctions enjoy the same freedom and equal rights as enjoyed by men and women in the West. Islam, further still regards women as precious and valuable, not to be disrespected or disgraced. The Muslim woman has been given roles, duties and as far back as 1400 years ago which most women are yet to enjoy today, even in the West. Summarily, Islam is a complete way of life.

\section{REFERENCES}

1. Clarke, K. M. (2006). Local Practices, Global Controversies: Islam in Sub-Saharan African Contexts. MacMillian, New Haven.

2. Erturk, Y. (2007). "Report of the Special Rapporteur on Violence Against Women, Its Causes and Consequence: Addendum Mission to Turkey Implementation of General Assembly Resolution 60/251 of 15 March 2006", Entitled "Human Rights Council." United Nations General Assembly, Accessed Online at http://www.wunrn.com/news/ on $6^{\text {th }}$ June, 2014

3. Lippman, T. (2002). Understanding Islam: An Introduction to the Muslim World, (New York: Plume Press).

4. Ediozie, R. K. (2005). Democratization in MultiReligious Contexts: Amina vs. The (Disunited) States of Nigeria. Local Practices, Global Controversies: Islam in Sub-Saharan African Contexts, 145.

5. Weiss, A. M. (2003). Interpreting Islam and Women's rights: Implementing CEDAW in Pakistan. International Sociology, 18(3), 581-601.

6. Wadud, A. (2009). Islam Beyond Patriarchy Through Gender Inclusive Qur'anic Analysis.
Wanted: Equality and Justice in the Muslim Family, 95-112.

7. An-Na'im, A.A. (2008). Islam and the Secular State: Negotiating the Future of Shari'a, (Harvard: Harvard University Press). Accessed online at http://www.timeshighereducation.co.uk/story.asp on $30^{\text {th }}$ May, 2014

8. Taimoor, B. (2006). "Women's Rights in Islam", Accessed Online at http://thepoliticus.com/content/women on 15 th April, 2016

9. Mahmoody, B. (1991). "Not Without My Daughter", Accessed Online at http://www.chasingthefrog.com/reelfaces/notwitho utmydaughter.php) on $22^{\text {nd }}$ April, 2016

10. Ragab, N. (2008). "The Record Set Straight: Women in Islam Have Rights", Accessed Online at http://www.submission.org/noha.html on 2nd May, 2015

11. Medina, X. (2014). "What do Muslim Women Want? Finding Women's Rights in Islam",

12. Hassan, R. (2005). "Members, One of Another: Gender Equality and Justice in Islam), Accessed Online http://www.religiousconsultation.org/hassan.htm on 6th February, 2016

13. Ladan, M. T. (1999). Introduction to International Human Rights and Humanitarian Laws, (Zaria: Ahmadu Bello University Press)

14. Al-Hibri, A.(2001). "Muslim Women's Rights in the Global Village: Challenges and Opportunities", Journal of Law and Religion 37, 40.

15. Al-Mahmoud. (2011). "Status of Mothers in Islam", Accessed Online at http://www.islamswomen.com/articles/mothers_in_ islam.php on 17th March, 2014

16. Kamguian, A. (2007). "Islam and the Liberation of Women in the Middle East: Separation of Mosque and State is the Only Answer", Free Inquiry Magazine, 23(4).

17. Ali, A. (1992). The Rights of Women in Islam (New York: St. Martin's Press, 1992)

18. Abou El Fadl, K. (2003). The Human Rights Commitment in Modern Islam. Human Rights and Responsibilities.

19. Oloka-Onyango, J., \& Tamale, S. (1995). The Personal is Political, or why Women's Rights are Indeed Human Rights: An African Perspective on International Feminism. Hum. Rts. Q., 17, 691.

20. Barlas, A. (2009). "The Qur'an, Shari'a and Women's Rights", Accessed Online at www.asmabarlas.com/TALKS on 15th March, 2014

21. Ali, M., \& Ali, A. (2011). Women's Liberation Through Islam. The Institute of Islamic Information and Education (III\&E). Accessed, 3.

22. Hassan, R. (2005), Are Human Rights Compatible with Islam? The Issue of the Rights of Women in Muslim Communities, (Kentucky: University of Louisville.) 
23. Messick, B. (2001). Messick, B. (2001). Indexing the Self-Intent and Expression in Islamic Legal Acts. Islamic Law and Society, 8(2), 151-178.

24. Obe, A. (2005). The Relationship between Divine and Human Law: Shari'a Law and the Nigerian Constitution. Local Practices, Global Controversies: Islam in Sub-Saharan African Contexts, 103.

25. Fox, D. J. (1998). Women's Human Rights in Africa: Beyond the Debate over the Universality or Relativity of Human Rights. African Studies Quarterly, 2(3), 3-16.
26. United, N. (1992). Violence Against Women. Women 2000, (4), 1.

27. Haleem, M. A. (1999). Human Rights in Islam and the United Nations Instruments. Democracy, the Rule of Law and Islam, London, The Hague, Boston, 435

28. The Holy, Qur'an. (1979). Translation of verses is heavily based on A. Yusuf Ali's translation, The Glorious Qur'an, text translation, and Commentary, The American Trust Publication, Plainfield, IN 46168,

29. BAOBAB for Women's Human Rights. (2003). Lagos, NIGERIA. 